\title{
Maastricht University graduate surveys 2016
}

Citation for published version (APA):

Levels, M. (2016). Maastricht University graduate surveys 2016. ROA. ROA Fact Sheets No. 001 https://doi.org/10.26481/umarof.2016001

Document status and date:

Published: 01/01/2016

DOI:

10.26481/umarof.2016001

Document Version:

Publisher's PDF, also known as Version of record

\section{Please check the document version of this publication:}

- A submitted manuscript is the version of the article upon submission and before peer-review. There can be important differences between the submitted version and the official published version of record.

People interested in the research are advised to contact the author for the final version of the publication, or visit the DOI to the publisher's website.

- The final author version and the galley proof are versions of the publication after peer review.

- The final published version features the final layout of the paper including the volume, issue and page numbers.

Link to publication

\footnotetext{
General rights rights.

- You may freely distribute the URL identifying the publication in the public portal. please follow below link for the End User Agreement:

www.umlib.nl/taverne-license

Take down policy

If you believe that this document breaches copyright please contact us at:

repository@maastrichtuniversity.nl

providing details and we will investigate your claim.
}

Copyright and moral rights for the publications made accessible in the public portal are retained by the authors and/or other copyright owners and it is a condition of accessing publications that users recognise and abide by the legal requirements associated with these

- Users may download and print one copy of any publication from the public portal for the purpose of private study or research.

- You may not further distribute the material or use it for any profit-making activity or commercial gain

If the publication is distributed under the terms of Article $25 \mathrm{fa}$ of the Dutch Copyright Act, indicated by the "Taverne" license above, 
Tuastricht University in Learning!

Research Centre for Education and the Labour Market | ROA

\section{Maastricht University graduate surveys 2016}

\section{ROA Fact Sheet}

ROA-F-2016/1

Researchcentrum voor Onderwijs en Arbeidsmarkt | ROA Research Centre For Education and the Labour Market / ROA 


\section{Maastricht University graduate surveys 2016}

To what degree does Maastricht University succeed in preparing its students for the labour market? What are the short and medium term career paths of Maastricht University alumni, and how do they look back on their study in Maastricht? In this factsheet, the most important results of a 2015 survey amongst three cohorts of Maastricht University alumni are presented. The first cohort graduated in the academic year 2013-20I4 (I.5 years prior to the survey), the second cohort graduated in 2009-20Io (6 years prior to the survey) and the third cohort in the academic year 2004-2005 (II years prior to the survey)., ${ }^{1,2}$ In addition, this year the comparison between Maastricht University and national results can be made for the cohort 2013-20I4 and for the cohort 2009-20I0.3.4

\section{Position in the labour market}

Table I gives a detailed overview of graduates' unemployment rates - that is, the proportion of graduates who are currently not working but who are searching for work. On average in other Dutch universities $5 \%$ of the graduates from the 20I3-20I4 cohort and $4 \%$ of the graduates from the 2009-20IO cohort are unemployed. Of Maastricht University alumni, $7 \%$ of the $2013-2014$ cohort is currently unemployed, while this only applies to $3 \%$ of the 20092010 cohort and $3 \%$ of the $2004-2005$ cohort. $^{6}$ The higher unemployment rate of the 2013-20I4 cohort may reflect the aftermath of recent recessions, that have hampered the transition from university to work for graduates in the years directly following 2008 (see also previous factsheets).

How well do graduates from different faculties fare? In the 2013-20I4 cohort, unemployment rates are highest among graduates of Law or Psychology and Neuroscience. However, in both the 2009-2010 and the 2004-2005

I Of the 2013-20I4 Maastricht University cohort, 2.676 alumni were approached, of whom $26 \%$ responded. For the 2009-2010 Maastricht University cohort, of the I826 alumni were approached, $26 \%$ responded. Finally, for the 2004-2005 Maastricht University cohort, of the 1895 alumni that were approached, $29 \%$ responded.

2 The reader should keep in mind that the mix of studies offered by Maastricht University the respondents graduated from may vary between the three cohorts.

3 For the cohort 2009-20I0 an adjustment weight is assigned due to the limited number of universities participating in comparison to the cohort from 20I3-20I4.

4 Of the 2013-20I4 national cohort, 37.962 respondents were approached, of whom $21 \%$ responded. For the 2009-20I0 national cohort, 2I.264 respondents were approached and $17 \%$ responded.

5 UvA, TU Delft, TU Eindhoven, RUG, RU, EUR, and UU

6 The unemployment rate might also vary within faculties. For example, in case of the Faculty of Health, Medicine and Life Sciences, the unemployment of Medical alumni is 3\% I.5 years after graduation, whereas for Health and life Sciences alumni the unemployment rate among the same cohort is $7 \%$. cohorts, unemployment rates are the highest among Arts and Social Sciences graduates. ${ }^{7}$ We can conclude that labour market participation is higher for the 2009-2010 and 20042005 cohorts of Maastricht university graduates, but is considerably lower for the 20I3-20I4 cohorts.

Table 1

Unemployment ${ }^{8}$

\begin{tabular}{|l|c|c|c|} 
& \multicolumn{3}{|c|}{ \% unemployed } \\
\hline Humanities and Sciences & $2013-2014$ & $2009-2010$ & $2004-2005$ \\
\hline Business and Economics & 4 & 6 & $0 / x$ \\
\hline Health, Medicine and Life Sciences & 7 & 2 & 4 \\
\hline Arts and Social Sciences & 4 & 5 & 2 \\
\hline Psychology and Neuroscience & 10 & 7 & 12 \\
\hline Law & 10 & 3 & 3 \\
\hline Maastricht University & 7 & 2 & 0 \\
\hline National averages & 6 & 3 & 3 \\
\hline x = too few cases; N/A = not available & & & N/A \\
\hline
\end{tabular}

\section{Trends in unemployment}

To what extent has the recent economic crisis affected labour market opportunities of Maastricht University graduates since 2008? An indication can be found in the average unemployment rate of Maastricht University graduates, as reported by the surveys that were held between 2005 and 20I5. For all eleven years that these surveys were conducted, unemployment information of the three cohorts is available. For the two cohorts that are 6 or II years on the labour market, no clear trend in unemployment rates can be detected. Thus, the most recent economic crisis does not seem to have had an influence on the unemployment rate of Maastricht University alumni 6 to II years into their labour market. Nevertheless, a notable trend in unemployment rates can be observed when analysing the data of graduates one year after graduation (see Figure I). Between 2007 and 2013, unemployment rates one year after graduation have risen steadily. Since 2013 , the unemployment rates of graduates one year after graduating have sharply decreased, and are almost back to pre-economic crisis levels. In Appendix A, yearly employment rates are reported per faculty.

7 In the 2004-2005 cohort too few cases from Humanities and Sciences were available for reliable statistical analyses.

8 Compared to preceding years, starting in 2015 we use a slightly different definition of employment status in the surveys among alumni who graduated 6 and II years prior to the survey. Whereas prior to 2015 a respondent had to report a working week of at least I2 hours to be considered as employed, from 2015 onwards the International Labour Organisation (ILO) definition applies, whereby all those who reported at least one hour of work are considered to be employed. In practice this makes little difference, since the vast majority of those employed are working fulltime, but it is possible that a small part of the change in unemployment in 2015 in those cohorts (between O.I and 0.5 percentage points) can be attributed to the definition change. 
Figure 1

Trends in unemployment of the T+1 survey ${ }^{\top}$

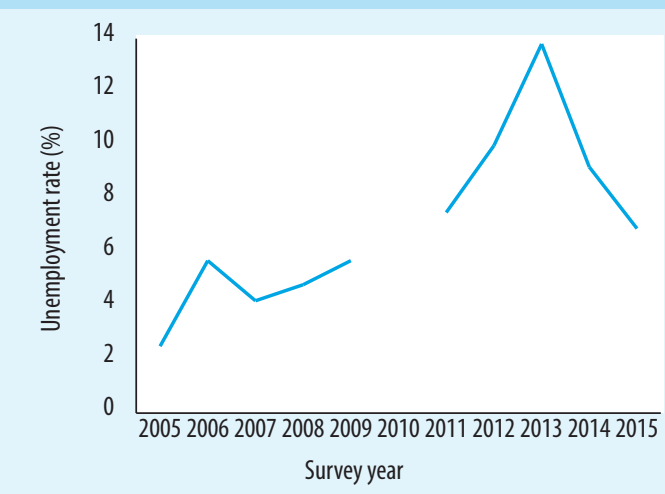

1 the $T+1$ survey was not administered in 2010

\section{Job characteristics}

It is important that graduates have a good match between their education and the requirements of their job, since this determines the extent to which they can use their knowledge and skills. ${ }^{9}$ The quality of the education-job match is positively related to job satisfaction, career opportunities, and wages. An important indicator of the quality of the fit between education and the job is the vertical match (i.e., whether graduates are working in a job that requires an academic degree). Table 2 a shows the results of the vertical match between graduates' current job and their level of education, for all three cohorts.

Table 2a

Vertical match

\begin{tabular}{|l|c|c|c|}
\hline & \multicolumn{4}{|c|}{$\%$ working at university level or higher } \\
\hline Humanities and Sciences & $2013-2014$ & $2009-2010$ & $2004-2005$ \\
\hline Business and Economics & 78 & $100 /$ x & $86 /$ x \\
\hline Health, Medicine and Life Sciences & 83 & 87 & 92 \\
\hline Arts and Social Sciences & 86 & 91 & 95 \\
\hline Psychology and Neuroscience & 79 & 83 & 91 \\
\hline Law & 73 & 97 & 97 \\
\hline Maastricht University & 81 & 94 & 96 \\
\hline $\begin{array}{l}\text { National average } \\
\text { X too few cases, N/A = not available }\end{array}$ & 69 & 80 & 94 \\
\hline
\end{tabular}

Table 2 a shows that the vast majority of graduates succeeds in finding a job at an appropriate level. However, the results of the vertical match are substantially different for the three cohorts. At a national level, of the cohort 2009$201083 \%$ is employed in a job at an appropriate level, and for the cohort $2013-201469 \%$ is working at university level

9 See for example: R. van der Velden (20II), De effecten van betrouwbaarheid van onderwijsdiploma's op arbeidsproductiviteit: toepassing van een simulatiemodel, In: J.Dronkers (ed.), Goede bedoelingen in het onderwijs: Kansen en missers, boekaflevering Mens en Maatschappij, pp 27-49. or higher. Maastricht graduates do significantly better. Among graduates from Maastricht University as a whole, the proportion of well-matched respondents decreases from $94 \%$ for the oldest cohort to $8 \mathrm{I} \%$ for the youngest cohort. There are some fluctuations between the cohorts. In general we may see relatively lower proportions of well-matched graduates in the Faculty of Arts and Social Sciences, and (the youngest cohorts of) the Faculty of Psychology and Neuroscience and the Faculty of Law. Relatively high numbers of graduates from the Faculties of Health, Medicine and Life Sciences, (the older cohorts of) Psychology and Neuroscience, and the Faculty of Law found a university level job. ${ }^{10}$

Table $2 \mathrm{~b}$ presents numbers on the horizontal educationto-job match. This indicator measures the proportion of Maastricht University graduates who currently work in a job that requires their own or a related field of study. Again, most graduates succeed in finding a job in a field that matches their field of study well. The three cohorts have different matching rates, with the results being most positive for both the 2009-2010 and the 2004-2005 cohorts. In the older cohorts, more graduates are working in their own or related field of study ( $80 \%)$ than in the recent cohort (77\%). Nationally, $74 \%$ of graduates from the cohort $2013-$ 2014 are working in their own or related field of study, compared to $77 \%$ from the cohort of 2009-20I0. Shortly after graduation, a horizontal mismatch is often related to labour market conditions not allowing graduates to find a job that matches the field of study, as well as voluntary choices preferring a job in a different field. II years after graduation, upward job mobility often comes with more 'generic' positions that are not directly related to the initial field of study.

Table $2 b$

Horizontal match

\begin{tabular}{|l|c|c|c|}
\hline & \multicolumn{4}{|c|}{ \% working in own or related field of study } \\
\hline Humanities and Sciences & $2013-2014$ & $2009-2010$ & $2004-2005$ \\
\hline Business and Economics & 57 & $81 / x$ & $86 / \mathrm{x}$ \\
\hline Health, Medicine and Life Sciences & 77 & 74 & 73 \\
\hline Arts and Social Sciences & 89 & 92 & 87 \\
\hline Psychology and Neuroscience & 63 & 60 & 50 \\
\hline Law & 72 & 87 & 84 \\
\hline Maastricht University & 71 & 83 & 81 \\
\hline National average & 77 & 80 & 80 \\
\hline X too few cases; N/A = not available & 74 & 77 & N/A \\
\hline
\end{tabular}

Io For the Faculty of Health, Medicine and life Sciences a strong difference is again visible between Medicine and Health and Life Sciences. Graduates of the latter studies are vertically matched in $90 \%$ (2013-2014), 86\% (2009-2010), and 93\% (2004-2005) of the cases, while graduates of Medicine are vertically matched in 95\% (2013-20I4) and 100\% (both 2009-20I0 and 2004-2005 cohort) of the cases. 
Next to differences between the three cohorts, we may observe differences between the faculties. Overall, graduates from the Faculties of Arts and Social Sciences show lower proportions of well-matched graduates. Graduates from both Humanities and Sciences and Psychology and Neuroscience have relatively more difficulty finding a matching job right after graduation, but their horizontal match rate rises sharply as the career progresses. Graduates from the School of Business and Economics have a better chance at finding a job in their own or related field right after graduation, but their match rate does not rise over the years. There is little systematic difference between the remaining faculties. It should be noted, however, that within the Faculty of Health, Medicine and Life Sciences, a strong distinction can be seen between the study of Medicine and the studies of Health and Life Sciences. Because of the very specific nature of their study, Medicine graduates show a considerably better horizontal match in all three cohorts (2013-20I4: 95\%, 2009-200I0: 100\%, 2004-2005: 100\%) than the graduates of Health and Life Sciences studies (2013-20I4: 86\%, 2009-20I0: 91\%, 2004-2005: 81\%).

\section{Income and working hours}

Table 3 shows that, as can be expected, as working experience increases, the median gross income of Maastricht University alumni increases. More specifically, I, 5 years after graduation, Maastricht University alumni have a median income of $€ 2$.53I per month, while this increases to $€ 35006$ years after graduation and $€ 4.300$ II years after graduation. These numbers closely match the results of previous surveys. Although the income patterns across disciplines slightly differ between the different survey years, Business and Economics graduates consistently show the highest monthly earnings and Arts and Social Sciences graduates the lowest. ${ }^{\text {II }}$ It should be noted however, that graduates of the top income discipline (Business and Economics) also report the highest working hours, compared to graduates of the other disciplines. Compared to national gross incomes of graduates, Maastricht University graduates yield comparable returns to their education: 1,5 years after graduation the median income is $€ 2500$ per month and 6 years after graduation this has increased to $€ 3400$ per month. The median working hours on national level is 40 for both the 2013-20I4 and the 2009-20Io cohort.

II The relatively low median income of Health, Medicine and Life Sciences graduates, is strongly influenced by the relatively low median income of the Health and Life Sciences studies. Medical graduates (a) have a higher starting salary and (b) are the best paid alumni II years after graduation, with a median income of $€ 5150$. Due to the structure of their career paths, Medical alumni are also the group that displays the biggest income growth between six and eleven years after graduation.
Table 3

Income and working hours

\begin{tabular}{|l|c|c|c|r|r|r|}
\hline & \multicolumn{3}{|c|}{ gross income per month } & \multicolumn{3}{c|}{ regular working hours } \\
& 2013 & 2009 & 2004 & 2013 & 2009 & 2004 \\
\hline & - & - & - & - & - & - \\
\hline & 2014 & 2010 & 2005 & 2014 & 2010 & 2005 \\
\hline Humanities and Sciences & 2.754 & $3.700 / x$ & $4.150 / x$ & 40 & $40 / x$ & $40 / x$ \\
\hline Business and Economics & 3.000 & 5.000 & 5.650 & 40 & 40 & 40 \\
\hline Health, Medicine and Life Sciences & 2.770 & 3.250 & 4.000 & 38 & 38 & 36 \\
\hline Arts and Social Sciences & 1.350 & 2.450 & 3.000 & 39 & 40 & 40 \\
\hline Psychology and Neuroscience & 2.100 & 3.000 & 3.729 & 38 & 39 & 36 \\
\hline Law & 2.433 & 3.360 & 4.422 & 40 & 40 & 40 \\
\hline Maastricht University & 2.531 & 3.500 & 4.300 & 40 & 40 & 38 \\
\hline National average & 2.500 & 3.400 & N/A & 40 & 40 & N/A \\
\hline
\end{tabular}

\section{Aspects of the current job}

Graduates in the 2004-2005 and 2009-2010 cohorts were asked to report the extent to which a number of features apply to their current job. Table 4 presents a selection of three of these features, namely job security, new challenges and career perspectives. Shown in the table is the percentage of graduates who reported that these features applied to a high or very high extent to their current job. Graduates often reported that their job is characterized by new challenges: around $90 \%$ of graduates in both cohorts reported that this was the case. Around two thirds reported that their jobs were characterized by a high level of job security, while about three quarters of the graduates reported that the job was characterized by good career perspectives. Interestingly, although the older cohorts showed somewhat higher proportions of respondents that were satisfied with the new challenges their jobs offered, they were slightly less satisfied with the career perspectives and job security. It seems likely that the careers of older graduates have stabilized somewhat after a period of early growth and improvement.

Table 4

Percentage of respondents who reported that these features applied to a high or very high extent to their current job

\begin{tabular}{|l|r|r|r|r|r|r|}
\hline & \multicolumn{2}{|c|}{ job security } & new challenges & \multicolumn{2}{c|}{$\begin{array}{c}\text { career } \\
\text { perspectives }\end{array}$} \\
& $2009-$ & $2004-$ & $2009-$ & $2004-$ & $2009-$ & $2004-$ \\
& 2010 & 2005 & 2010 & 2005 & 2010 & 2005 \\
\hline Humanities and Sciences & $56 /$ x & $83 /$ x & $94 /$ x & $83 /$ x & $81 /$ x & $83 /$ x \\
\hline Business and Economics & 64 & 51 & 91 & 95 & 90 & 79 \\
\hline Health, Medicine and Life Sciences & 66 & 71 & 87 & 87 & 79 & 68 \\
\hline Arts and Social Sciences & 71 & 65 & 85 & 100 & 88 & 55 \\
\hline Psychology and Neuroscience & 75 & 85 & 91 & 85 & 91 & 63 \\
\hline Law & 71 & 67 & 87 & 87 & 84 & 73 \\
\hline Maastricht University & 67 & 65 & 89 & 90 & 86 & 71 \\
\hline National average & 64 & N/A & 89 & N/A & 76 & N/A \\
\hline X & 75 & & &
\end{tabular}


The differences between faculties for the older cohorts are the largest for job security, where Psychology and Neuroscience graduates reported highest levels of job security and the graduates of Business and Economics report the lowest levels of job security. Regarding new challenges in their job, the graduates of Arts and Social Sciences report the highest level and the graduates from Psychology and Neuroscience the lowest. The Business and Economics graduates report the most career perspectives, and the Arts and Social Sciences graduates the lowest.

The graduates who were approached 6 years after graduation report smaller differences. Psychology and Neuroscience graduates in this cohort enjoy a relatively high level of job security, whereas this applies to a little over a half of their Humanities and Sciences peers. Graduates from Humanities and Sciences are relatively likely to report a high level of new challenges, but the lowest level of career opportunities. New challenges are reported the least by graduates from Arts and Social Sciences, and graduates from the Faculty of Psychology and Neuroscience score relatively high on career perspectives. Compared to national numbers for the 2009 -20I0 cohort, $64 \%$ reports enjoying a relatively high level of job security, $89 \%$ reports a high level of new challenges and $76 \%$ states good career perspectives.

\section{International orientation of Maastricht University and its graduates}

It appears that the international orientation of Maastricht University and the fact that English is the main language of instruction in many study programs continue to attract increasing numbers of international students for all faculties. It is interesting to see whether this international orientation extends beyond the time of the study in Maastricht, in the form of high percentages of graduates working abroad. Table 5 shows the percentage of Maastricht University alumni of the various cohorts currently working inside and outside the Netherlands, split by faculty. For Maastricht as a whole, $46 \%$ of the alumni of 2013-20I4 cohort is working abroad, while the same applies to $42 \%$ of the alumni of the 2009-20Io cohort and $23 \%$ of the alumni of the 2004 2005 cohort. These numbers include foreign students who returned to their home country after graduation. ${ }^{\text {I2 }}$
Table 5

Percentage of alumi working abroad

\begin{tabular}{|l|c|c|c|}
\hline & \multicolumn{3}{|c|}{ \% working abroad } \\
\hline Humanities and Sciences & $2013-2014$ & $2009-2010$ & $2004-2005$ \\
\hline Business and Economics & 52 & $69 / x$ & $29 / x$ \\
\hline Health, Medicine and Life Sciences & 65 & 64 & 45 \\
\hline Arts and Social Sciences & 21 & 16 & 8 \\
\hline Psychology and Neuroscience & 73 & 55 & 39 \\
\hline Law & 56 & 33 & 23 \\
\hline Maastricht University & 36 & 28 & 19 \\
\hline National average & 46 & 42 & 23 \\
\hline
\end{tabular}

$\mathrm{x}=$ too few cases; $\mathrm{N} / \mathrm{A}=$ not available

Considerable variation exists between the faculties. Graduates of the Arts and Social Sciences and Business and Economics are particularly internationally active, while for Law and especially Health, Medicine and Life Sciences graduates' international mobility is relatively rare. The pattern of diminished mobility for the older cohorts can be seen in all faculties, despite the large differences in the absolute level of international mobility. Only for Humanities and Sciences there are more graduates working abroad from the 2009-20IO cohort than from the 2013-20I4 cohort. On a national level, from the 20I3-20I4 cohort $17 \%$ is working abroad compared to just $4 \%$ of the $2009-2010$ cohort.

\section{Satisfaction with Maastricht University}

Finally, alumni were asked how they look back on their study at Maastricht University and to assess what choices they would have made in retrospect. With the benefit of hindsight, would graduates choose the same study at the same university again? In the $2013-2014$ cohort, $76 \%$ of the alumni would again choose the exact same study at Maastricht University. For the cohorts that graduated in 2009-20IO and 2004-2005, these figures were 78\% for both. Table 6 presents the survey results for the three cohorts per faculty. ${ }^{13}$
I2 We only show the general numbers here, and delve deeper in the international orientation, the origin and destination of graduates in the 2016 research report "Geographical mobility of Maastricht University graduates"
I3 Within the Faculty of Health, Medicine and Life Sciences, graduates of the Medical studies are significantly more satisfied with their study choice in retrospect. For example, in the 2004-2005 cohort, $71 \%$ of the graduates of Health and Life Sciences would again choose the same study at Maastricht university compared to $89 \%$ of the Medical graduates. 
Table 6

Percentage of alumi who would again choose the exact same study at Maastricht University

\begin{tabular}{|l|c|c|c|}
\hline Humanities and Sciences & $2013-2014$ & $2009-2010$ & $2004-2005$ \\
\hline Business and Economics & 74 & $88 / \mathrm{x}$ & $100 / \mathrm{x}$ \\
\hline Health, Medicine and Life Sciences & 80 & 82 & 78 \\
\hline Arts and Social Sciences & 78 & 78 & 75 \\
\hline Psychology and Neuroscience & 69 & 62 & 82 \\
\hline Law & 76 & 77 & 79 \\
\hline Maastricht University & 76 & 78 & 79 \\
\hline National average & 76 & 76 & N/A \\
\hline
\end{tabular}

$\mathrm{x}=$ too few cases; $\mathrm{N} / \mathrm{A}=$ not available

In general, graduates from the Faculties of Health, Medicine and Life Sciences, Business and Economics' and Psychology and Neuroscience (particularly the 2009-2010 cohort) are most often satisfied with their initial choice. Relatively less satisfied were graduates from Law and Arts and Social Sciences. Compared to national data, from both the graduates of the 2013-20I4 and 2009-20I0 cohort $76 \%$ would choose the same study at the same university again. 


\section{Appendix A}

Table 7

Trends in unemployment ${ }^{1,2}$

\begin{tabular}{|c|c|c|c|c|c|c|c|c|}
\hline & 2009 & 2010 & 2011 & 2012 & 2013 & 2014 & $2015 a$ & $2015 b$ \\
\hline & $\mathrm{T}+1$ & $\mathrm{~T}+1$ & $\mathrm{~T}+1$ & $\mathrm{~T}+1$ & $\mathrm{~T}+1$ & $\mathrm{~T}+1$ & $\mathrm{~T}+1$ & $\mathrm{~T}+1$ \\
\hline & $2007-2008$ & 2008-2009 & $2009-2010$ & $2010-2011$ & 2011-2012 & $2012-2013$ & 2013-2014 & 2014-2015 \\
\hline Business and Economics & 5,7 & - & 4,9 & 6,0 & 6,3 & 5,7 & 3,6 & - \\
\hline Health and Life Sciences & 0,0 & - & 4,4 & 8,3 & 16,4 & 10,3 & 9,2 & - \\
\hline Medicine & 0,0 & - & 0,0 & 1,7 & 2,5 & 3,3 & 2,7 & - \\
\hline Arts and Social Sciences & 18,5 & - & 23,9 & 25,5 & 33,3 & 13,7 & 5,9 & - \\
\hline Psychology and Neuroscience & 6,1 & - & 11,4 & 16,7 & 25,6 & 7,6 & 10,3 & - \\
\hline Law & 6,0 & - & 8,8 & 7,1 & 14,3 & 16,2 & 10,3 & - \\
\hline \multirow[t]{4}{*}{ Maastricht University } & 5,7 & - & 7,5 & 10,0 & 13,8 & 9,2 & 6,9 & - \\
\hline & 2009 & 2010 & 2011 & 2012 & 2013 & 2014 & $2015 a$ & $2015 b$ \\
\hline & $\mathrm{T}+5$ & $\mathrm{~T}+5$ & $\mathrm{~T}+5$ & $\mathrm{~T}+5$ & $\mathrm{~T}+5$ & $\mathrm{~T}+5$ & $\mathrm{~T}+5$ & $\mathrm{~T}+5$ \\
\hline & $2002-2003$ & 2003-2004 & $2004-2005$ & $2005-2006$ & $2006-2007$ & $2007-2008$ & 2008-2009 & $2009-2010$ \\
\hline Business and Economics & 3,2 & 2,2 & 5,4 & 1,9 & 0,0 & 0,0 & 0,9 & 1,5 \\
\hline Health and Life Sciences & 2,4 & 1,7 & 2,7 & 2,1 & 3,1 & 3,5 & 4,3 & 5,3 \\
\hline Medicine & 0,0 & 0,0 & 1,5 & 0,0 & 0,0 & 1,3 & 0,0 & 4,9 \\
\hline Arts and Social Sciences & $x$ & $x$ & 3,8 & 10,1 & 5,7 & 4,8 & 4,4 & 6,7 \\
\hline Psychology and Neuroscience & 1,9 & 7,0 & 10,3 & 4,2 & 0,0 & 4,3 & 7,5 & 2,5 \\
\hline Law & 1,2 & 4,3 & 5,0 & 0,0 & 6,8 & 3,8 & 2,6 & 1,8 \\
\hline \multirow[t]{4}{*}{ Maastricht University } & 2,3 & 2,5 & 4,4 & 2,7 & 3,2 & 2,6 & 2,6 & 3,4 \\
\hline & 2009 & 2010 & 2011 & 2012 & 2013 & 2014 & $2015 a$ & $2015 b$ \\
\hline & $\mathrm{T}+10$ & $\mathrm{~T}+10$ & $\mathrm{~T}+10$ & $\mathrm{~T}+10$ & $\mathrm{~T}+10$ & $\mathrm{~T}+10$ & $\mathrm{~T}+10$ & $\mathrm{~T}+10$ \\
\hline & 1997-1998 & 1998-1999 & $1999-2000$ & $2000-2001$ & $2001-2002$ & $2002-2003$ & 2003-2004 & $2004-2005$ \\
\hline Business and Economics & 0,0 & 3,0 & 2,8 & 0,9 & 0,9 & 0,7 & 1,0 & 0,0 \\
\hline Health and Life Sciences & 0,6 & 0,6 & 2,0 & 1,2 & 3,1 & 3,7 & 0,6 & 2,6 \\
\hline Medicine & 0,0 & 0,0 & 2,6 & 1,8 & 0,0 & 2,0 & 3,6 & 1,5 \\
\hline Arts and Social Sciences & $x$ & $x$ & $x$ & $x$ & $x$ & $x$ & 4,3 & $11,5^{3}$ \\
\hline Psychology and Neuroscience & 0,0 & 0,0 & 0,0 & 3,8 & 0,0 & 4,9 & 2,0 & 3,1 \\
\hline Law & 0,0 & 1,5 & 0,0 & 6,1 & 1,6 & 0,0 & 1,4 & 0,0 \\
\hline Maastricht University & 0,3 & 1,7 & 2,0 & 2,0 & 2,0 & 2,1 & 1,5 & 3,0 \\
\hline
\end{tabular}

$1=$ too little information on the Faculty of Humanities and Sciences

$2=$ It should be noted that a slightly different definition of employment status was used in the $T+5$ and $T+10$ surveys in 2015 than in the preceding years. Whereas prior to 2015 a respondent had to report a working week of at least 12 hours to be considered as employed, from 2015 onwards the International Labour Organisation (ILO) definition applies, whereby all those who reported at least one hour of work are considered to be employed. In practice this makes little difference, since the vast majority of those employed are working fulltime, but it is possible that a small part of the change in unemployment in 2015 in those cohorts can be attributed to the definition change.

$3=$ this trend should be interpreted with care. The number of respondents is relatively low which can lead to relatively large fluctuations. More data points are needed before a trend can be safely interpreted.

$\mathrm{x}=$ too few cases

- = the T+1 survey was not administered in 2010 and still has to be administered in 2016 


\section{Colofon}

Copyright (C) 2015, Research Centre for Education and the Labour Market, Maastricht. No part of this publication may be reproduced in any way without prior permission of the Director of ROA.

\section{Research Centre for Education and the Labour Market}

P.O. Box 616

6200 MD Maastricht

The Netherlands

secretary-roa-sbe@maastrichtuniversity.nl

www.roa.nl

\section{Maastricht University}

School of Business and Economics

\section{Layout}

ROA secretary, Maastricht

June 2016 
Researchcentrum voor Onderwijs en Arbeidsmarkt

Postbus 616

6200 MD Maastricht

$\mathrm{T}+31433883647$

F +31 433884914

secretary-roa-sbe@maastrichtuniversity.nl

www.roa.nl

Maastricht University

School of Business and Economics 